\title{
3409 鉄道車両シート着座時の下肢むくみ調査
}

Investigation of the leg swelling during sitting on the train seat

O学 山口穂高（信州大学大学院） 正 吉田宏昭（信州大学）．正 上條正義（信州大学大学院）
松本泰幸(コイト電工株式会社）

\author{
Hodaka YAMAGUCHI, Graduate school of Shinshu University, 3-15-1 Tokida, Ueda, Nagano, 386-8567, Japan \\ Hiroaki YOSHIDA, Masayoshi KAMIJO, Shinshu University \\ Yasuyuki MATSUMOTO, Koito Electric Industries, LTD.
}

\begin{abstract}
To examine sitting comfort is important to decrease fatigue due to long-term sitting on the train seats. We focused on leg swelling which occurs during sitting, and investigated it with use of both bioelectrical impedance method and sensory testing. Sitting experiment was performed by using four kinds of footrest angle, three kinds of cushion firmness, and two kinds of experimental timing (AM or PM). From the results, we found that leg swelling decreased while sitting under the condition of 30 degree for footrest angle. It is considered that there is an appropriate combination of footrest angle and cushion firmness.
\end{abstract}

Key Words: Sitting comfort, Leg swelling, Bioelectrical impedance method, Sensory testing, Train seat.

1. はじめに

長時間着座姿勢を取り続ける必要がある鉄道車内におい て，常に身体に接触し支えている座席シートは乗客の快適性 に大きな影響を与えている。特に下肢のむくみは着座による 大腿部の圧迫や筋肉の活動を制限される条件下で発生しや すく, 快適性を損なう原因のひとつである.むくみとは細胞 外の間質液が過剩に貯まり, 体積が膨張する現象であり, 着 座時における下肢のむくみは下肢循環系の滞りにより発生 するとされている.

一方, 鉄道の中でも優等車両には快適感の付加とむくみ抑 制の目的でフットレストが設置されていることが多い:しか しながら，設置にあたっては明確な設計基準が無く，どのよ

うな下肢姿勢を取らせることが快適感やむくみの抑制に対 してよいかといった調查は十分に行われていない.

本研究では鉄道車両用シート着座時にフットレストを用 い, 足首の角度を変化させることでむくみがどのように変化 するかを調査した．加えて，多くの要因で変化するむくみを 捉えるために座面硬さおよび着座の時間帯によるむくみの 違いも同時に調査したので報告する.

\section{2. 方法}

\section{2-1 実験概要}

本研究では, 20代男性12名を被験者とし実際の鉄道車両用 シートと高さを変えず角度が変化するように作成したフッ トレストを用いて着座実験を行った，被験者は座面硬さの3 条件 (Soft - Normal - Hard) と時閒帯の2条件 (午前10:00 . 午後2:00 ), 計6条件に2名ずつランダムに振り分けられ, そ れぞれフットレスト角度 $0^{\circ} \cdot 10^{\circ} \cdot 20^{\circ} \cdot 30^{\circ}$ の 4 条件に着座し た. 各被験者は1日1条件のみの着座とし,フットレスト角度 の提示順は被験者ごとにランダムとした．また，着座姿勢は 山口ら[1]の研究における準休息姿勢とし, リクライニング角 を 110 に設定した. 着座時間は30分間とし, 着座中は座り直 しを許可せず，体動を可能な限り抑えるように指示をした。

着座実験中の計測項目は下肢関節角度，下肢むくみ，官能 検査の3項目であった. むくみ測定は着座の直後より5分おき に計7回, 生体インピーダンス法を用いて行い, 着座の直後 と着座30分後の計2回官能検査を行った。 また, 着座中の姿 勢を捉えるために加速度センサを下肢の各部位に貼付し着 座中の下肢関節角度を求めた。

\section{2-2 下肢関節角度の測定}

下肢の姿勢を捉えるために被験者の腰・左大腿表・左下腿 表・左足甲の 4 か所に 3 軸加速度センサ（マイクロストーン
株式会社製 MVP-RF8）を添付した．解析においては，重力 加速度とセンサの加速度のつり合い式から人体矢状面にお ける水平からの角度を算出し, 最終的には各部位の角度の差 から関節角度を求めた（図 1).

(1) 腰角度

(2) 腰関節角度

(3) 膝角度

(4) 足首角度

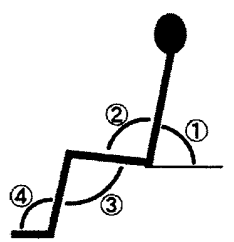

図 1 下肢関節角度算出箇所

\section{2-3 生体インピーダンス法を用いたむくみの測定}

生体インピーダンス法とは生体の電気抵抗を測定するこ とで体組成を推定する方法である.むくみの発生により細胞 外の水分量が増加し, 結果として抵抗值が減少するため, こ の抵抗值の逆数をBI值とし值が大きくなるほどむくみ増加 を表す指標として用いた. 結果をまとめる際は着座直後のBI 值で各時刻のBI值を基準化したむくみの変化率に変換した.

測定機材は SK メディカル電子株式会社のMLT-50を用 い, 両足首間に貼付した電極から着座開始より5分おきにBI 值を取得した.

\section{2-4 官能検査}

アンケートの項目は首・有・背中・腰・臂部・大腿・下腿 それぞれの痛み感・だるさ感・快適感と全体の快適感と疲労 感の計23項目とし，それぞれ7段階で評価を得た．解析にお いては, 着座に伴う変化をみるために着座 30 分後の評点から 着座直後の評点を引いた評点の増加量を求めた.

\section{3. 結果と考察}

\section{3-1 下肢関節角度の測定}

表1にフットレスト角度と座面硬さにおける下肢関節角度 の結果を示す．なお，実験時間帯は着座時の下肢関節角度に 影響を与えないものと考え, 結果は午前・午後のグループを 含めた平均值を示している.

この結果より,フットレストによって足首関節の角度が大 きく変化するが, これに協調するように腰の角度と腰関節も 足首角度を大きくすると折りたたまれるように变化してい ることがわかる。この変化は座面の柔らかいものでは腎部が 沈み込むために小さくなり，硬めの座面では沈み込みが少な いために顕著に表れた。

[No. 12-79] 日本機械学会 第 21 回交通・物流部門大会 講演論文集 [2012-12.5 7. 東京] 
表 1 下肢関節角度結果

\begin{tabular}{|c|c|c|c|c|c|}
\hline 座面圙さ & フットレスト & 腰角度 & 腰笑節 & 脖笑節 & 足首関節 \\
\hline \multirow{4}{*}{ Soft } & $0^{\circ}$ & $42.2^{\circ}$ & $144^{\circ}$ & $115^{\circ}$ & $145^{\circ}$ \\
\hline & $10^{\circ}$ & $38.0^{\circ}$ & $147^{\circ}$ & $114^{\circ}$ & $133^{\circ}$ \\
\hline & $20^{\circ}$ & $37.5^{\circ}$ & $147^{\circ}$ & $113^{\circ}$ & $121^{\circ}$ \\
\hline & $30^{\circ}$ & $43.0^{\circ}$ & $139^{\circ}$ & $112^{\circ}$ & $115^{\circ}$ \\
\hline - & $0^{\circ}$ & $43.7^{\circ}$ & $141^{\circ}$ & $116^{\circ}$ & $140^{\circ}$ \\
\hline \multirow{3}{*}{ Normal } & $10^{\circ}$ & $45.3^{\circ}$ & $140^{\circ}$ & $116^{\circ}$ & $131^{\circ}$ \\
\hline & $20^{\circ}$ & $47.9^{\circ}$ & $137^{\circ}$ & $112^{\circ}$ & $121^{\circ}$ \\
\hline & $30^{\circ}$ & $50.2^{\circ}$ & $132^{\circ}$ & $112^{\circ}$ & $113^{\circ}$ \\
\hline \multirow{4}{*}{ Hard } & $0^{\circ}$ & $39.4^{\circ}$ & $146^{\circ}$ & $107^{\circ}$ & $131^{\circ}$ \\
\hline & $10^{\circ}$ & $41.3^{\circ}$ & $146^{\circ}$ & $116^{\circ}$ & $129^{\circ}$ \\
\hline & $20^{\circ}$ & $39.5^{\circ}$ & $145^{\circ}$ & $112^{\circ}$ & $121^{\circ}$ \\
\hline & $30^{\circ}$ & $49.4^{\circ}$ & $138^{\circ}$ & $114^{\circ}$ & $113^{\circ}$ \\
\hline
\end{tabular}

\section{3-2 むくみの測定}

図2に6条件それぞれのむくみの変化を示す．

まずフットレスト角度に着目すると，ほとんどの条件下で フットレスト角度 $30^{\circ}$ においてむくみが抑制される結果と なった。これは下肢関節角度結果より示唆された, 足首を挙 げることによる腰関節の協調作用によって, 大腿部の圧迫が ほかの角度よりも軽減され，むくみが抑制されたものと考え られる.この大腿部の圧迫を検証するために着座時の座面圧 力を測定したが，フットレスト角度が大きいほど大腿下の圧 迫が抑えられるといった結果を支持するデータが得られた。

さらに, Hardを除いた条件では午後に計測を行ったフット レスト角度 $30^{\circ}$ において着座直後のむくみよりも減少する 結果となった. 午後は午前に比べ被験者が運動をした状態で 着座をしたため, 蓄積されたむくみが着座によって解消され たと考えることができる．

しかしながら，座面硬さHardの条件においてはこの午後の むくみ解消作用が見られず，他の座面硬さよりも午後の使用 には適していない可能性が示唆された。

また，いずれの条件においても $0^{\circ}$ 条件が一番むくむとい う結果にはならず, 足首角度を若干つけることはかえって亜 影響になることも示唆された。

\section{3-3 官能検査}

図3に6条件それぞれの官能検査の結果を示す。この際，む くみとの対応を見るために下肢の痛み感とだるさ感に着目 した.

この結果より，ほとんどの条件で評点の増加が見られ30分 の着座において痛み感・だるさ感の増加を誘発するが，むく み測定によってむくみ解消の結果が得られたSoft午後と $\mathrm{Normal}$ 午後のフットレスト角度 $30^{\circ}$ において他の角度より も痛み感・だるさ感の増加が抑えられ, 被験者もむくみの解 消をある程度知覚していたことがわかる．また，Hard条件は 他の硬さに比べ全体的に不快感の増加が抑えられる傾向も 観察されたが，各条件の被験者数が少ないため，条件ごとに 大きな違いを得るまでには至らなかった。

\section{4. まとめ}

むくみについては $30^{\circ}$ のフットレストを使用することで 抑制される結果が得られた、フットレスト角度 $30^{\circ}$ では足首 角度の増加により腰関節も協調的に姿勢を制御し, 結果とし て大腿部の圧迫が他の角度よりも抑えられたことによりむ くみが抑制されたものと考えられる.さらに午後の着座では フットレスト角度 $30^{\circ}$ でむくみが解消されるといった結果 が得られ, 官能検查の結果からもこのむくみの解消を被験者 が知覚していることも示唆された. しかし，このむくみの解

消は座面硬さが硬いものでは観察されなかった。このことよ り，座面硬さとフットレストの角度には適した組み合わせが あることが予想される。 今後は被験者の増加や, 着座時間の 考慮, さらに大きな角度のフットレストの検討等を行ってい く必要がある。

\section{参考文献}

[1]山口穂高ら: 有限要素解析を用いた鉄道車両用シートの座 り心地に関する研究, 日本感性工学会論文誌Vol. 11 (2012) No. 4 p. $519-525$

午前

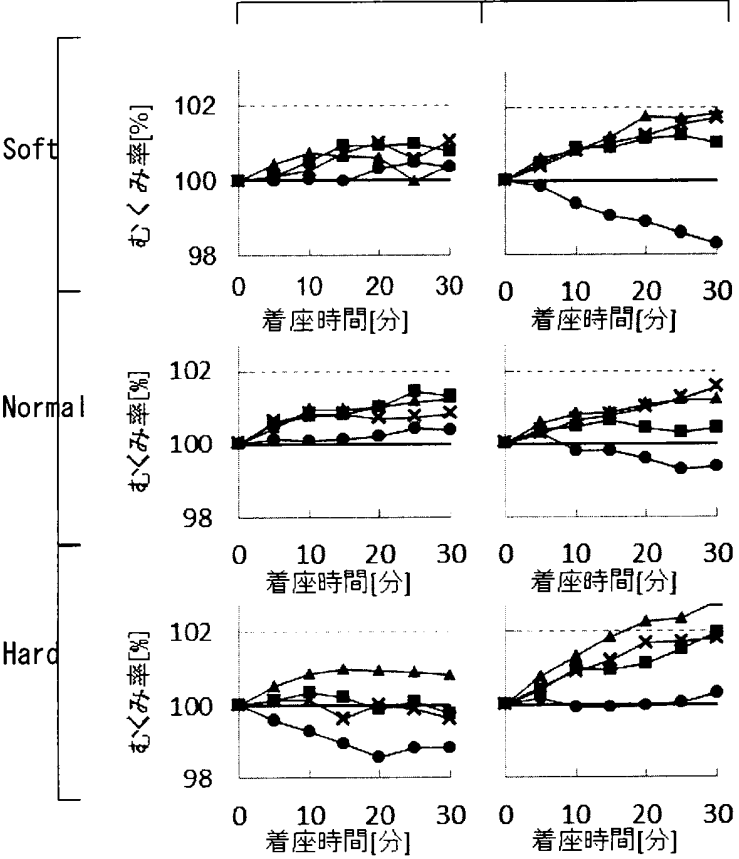

図 2 むくみの変化 $\left(\times 0^{\circ}, \Delta 10^{\circ},=20^{\circ}, \bullet 30^{\circ}\right)$
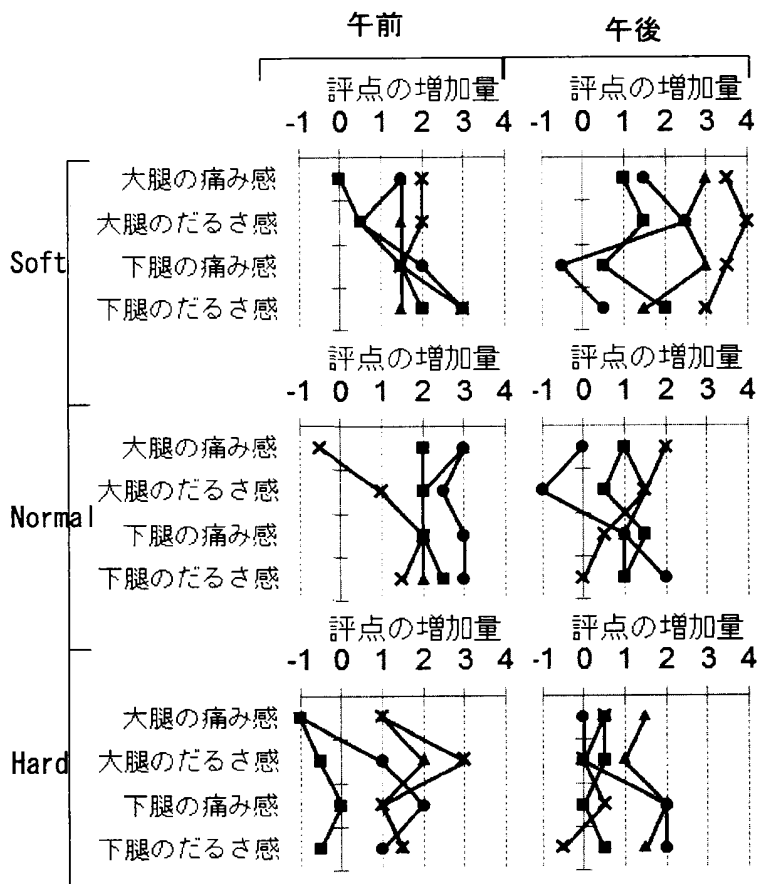

図 3 官能検查 $\left(\times 0^{\circ}, \Delta 10^{\circ},-20^{\circ}, \bullet 30^{\circ}\right)$ 